\title{
Kierkegaard and the Search for Self-Knowledge
}

\author{
Daniel Watts
}

\begin{abstract}
In the first part of this essay (Sections I and II), I argue that Kierkegaard's work helps us to articulate and defend two basic requirements on searching for knowledge of one's own judgements: first, that searching for knowledge whether one judges that P requires trying to make a judgement whether P; and second that, in an important range of cases, searching for knowledge of one's own judgements requires attending to how one's acts of judging are performed. In the second part of the essay (Sections III and IV), I consider two prima facie problems regarding this conception of searching for knowledge of one's own judgements. The first problem concerns how in general one can coherently try to meet both these requirements at once; the second, how in particular one can try to attend to one's own acts of judging. I show how Kierkegaard's work is alive to both these problems, and helps us to see how they can be resolved.
\end{abstract}

Kierkegaard's writings often exhibit a special interest in the injunction to know oneself, and in the question of what it would be to truly heed this injunction. In this essay, I shall examine how Kierkegaard conceives of searching for self-knowledge, concentrating on the case of searching for knowledge of one's own judgements in particular. I make no assumption that Kierkegaard's own interest in the topic of self-knowledge is restricted in this way. ${ }^{1} \mathrm{My}$ aim, however, is to show that his writings provide us with a cogent and philosophically fertile account of what is involved in searching for knowledge of one's own judgements in particular.

I shall approach this aim by reference to two basic claims to which I hope to show Kierkegaard is committed and which can be summarized as follows:

(SK1) Searching for knowledge whether one judges that P requires (inter alia) trying to make a judgement whether P; and 
(SK2) For an important range of cases, searching for knowledge of one's own judgements requires (inter alia) attending to one's own acts of judging, how these acts are performed.

In general, we shall see how these claims, SK1 and SK2, are reflected in two corresponding perspectives on the search for self-knowledge, both of which find powerful expression in Kierkegaard's writings. In the one perspective, searching for self-knowledge properly involves a stance that is outward-looking and prospective, as per SK1; in the other perspective, by contrast, the appropriate stance for such inquiry is inward-looking and retrospective, as per SK2.

More particularly, I shall argue that SK1 is a major upshot of Kierkegaard's critique of a purely 'aesthetic' or contemplative conception of self-knowledge, especially as this critique is developed through his portraits of aesthetic and ethical life in Either / Or. According to this critique, searching for knowledge of one's own judgements cannot merely be a matter of contemplation of one's inner mental states; rather, this requires taking responsibility for oneself qua finite thinker, beholden to make judgements. Kierkegaard's view has an important bearing in this regard on current debates about self-knowledge, not least regarding the distinctive character of such knowledge and the role of deliberation in its acquisition.

On the other hand, however, and contrary to any impression that trying to 'make up one's mind' is all there is to searching for knowledge of one's judgements, I shall also argue that Kierkegaard is further committed to SK2. This claim, I submit, is grounded in the way he conceives human judgement in general, and ethical and religious judgement in particular. Specifically, SK2 is grounded in two important ideas: first, that our acts of judging are in general ultimately based on what I shall call primitive acts of judging, that is, acts of judging that are not based on further judgements but stand in an immediate and direct relationship to their subjectmatter; and second, that ethical and religious judgements are only properly identifiable as such by reference to thinkers' primitive acts of judging. I shall argue that, due to his commitment to 
these ideas, Kierkegaard thinks searching for knowledge of one's own judgements must in general include attending to one's own acts of judging, how these acts are performed.

My aim is not only to exhibit the Kierkegaardian credentials of SK1 and SK2, but also to indicate why I think these claims are worthy of serious consideration. However, I want further to consider two prima facie problems regarding the search for self-knowledge, so conceived. First: how can one coherently try to meet both requirements at once, given that they appear to pull in opposite directions? The challenge here is to make it intelligible how one can search in a way that is at once outward-looking and inward-looking, prospective and retrospective. Second: how - in what way, by what means - can we attend to our own acts of judging? The challenge here - I'll call it the problem of reflective opacity - is how to bridge the potential gap between one's reflectively endorsed judgements and one's primitive acts of judging. For the worry arises that, if one's selfawareness can be mediated by one's reflectively endorsed judgements, and if one's reflectively endorsed judgements can come adrift from one's primitive acts of judging, trying to attend to one's primitive acts of judging in a given case might be like trying to leap over one's own shadow.

We shall see that Kierkegaard regards these problems as real and pressing, but also that he provides resources for their resolution. In response to the first problem, regarding the unity of SK1 and SK2, these resources include Kierkegaard's striking conception of 'double reflection', as a certain kind of thinking and searching that is jointly constituted by abstract reflection and concrete self-examination, together with his rich reflections on Socrates' philosophical practice. In considering the second problem, regarding how we can attend to our own acts of judging, I shall introduce an idea I believe is central to Kierkegaard's literary practice, and which can be summarized by the following further claim:

(SK3) One can attend to one's own acts of judging indirectly, by attending to suitable objects of comparison. 
Finally, then, I shall try to show how 'objects of comparison' might play an important role in searching for knowledge of one's own judgements; and also to indicate why I think this idea helps to explain some of the most characteristic features of Kierkegaard's work as an author.

What might lead us in general to the idea of a 'search' for self-knowledge? After all, many philosophers are apparently of the view that knowing one's own mind is the default for human beings, self-deception a matter of deviation or aberration. ${ }^{2}$ Certainly, however, it would be implausible to deny that one can be intelligibly enjoined to search for self-knowledge, or that there are conditions in which this demand is warranted. And it seems far from obvious that these conditions are not in fact quite general and pervasive, given the manifold possibilities of failure in this domain. As Samuel Johnson characteristically put it:

If it be reasonable to estimate the difficulty of any enterprise by frequent miscarriages, it may justly be concluded that it is not easy for a man to know himself for wheresoever we turn our view, we shall find almost all with whom we converse so nearly as to judge of their sentiments, indulging more favourable conceptions of their own virtue than they have been able to impress upon others, and congratulating themselves upon degrees of excellence, which their fondest admirers cannot allow them to have attained Johnson 2003: 75).

The idea that self-knowledge is hard won and easily lost is no doubt far more plausible in the case of the moral sentiments to which Johnson refers than it would be in the case of one's occurent sensations, say (though there are occasions in which one may intelligibly wonder whether one's sensation is of a particular kind). But to deny that self-knowledge is always the 
outcome of a search is not to deny that there are perfectly familiar conditions in which it makes sense to ask about the condition of one's own mind, and to search for an answer. ${ }^{3}$

Now, Kierkegaard's writings are certainly among those that stand opposed to any general tendency to regard self-knowledge as default. Thus, according to one, typically sardonic entry from his journals, 'hypocrisy is as inseparable from being a man as sliminess from being a fish'. ${ }^{4}$ And it is a striking general feature of a work like The Sickness Unto Death that the idea of selfknowledge is approached via negativa, in terms of the absence of certain forms of self-blindness and self-estrangement, a perfected state in which these failures of self-knowledge have been finally 'rooted out'. To know oneself here is not to deceive oneself, where the possibilities of self-deception include the kinds of wilful refusal to identify with oneself Kierkegaard calls 'despair'.

If his work is plainly at odds with any general picture of self-knowledge as a reflex mechanism, this is not to say however that Kierkegaard rejects the very idea of self-knowledge or adopts a deflationary view of such knowledge. On the contrary, the following characterisation of 'the ethical individual' is typical of his writings in this regard: 'the ethical individual is transparent to himself ... has seen himself, knows himself, penetrates with consciousness his whole concretion' (Kierkegaard 1949: 216). And Kierkegaard's writings very often invoke the Socratic idea of the ability to distinguish between what one does and what one does not know or understand. ${ }^{5}$ In short, this work is not readily enlisted to the cause of those who would cast doubt on the very idea of self-knowledge or the ideal of self-transparency.

Given that Kierkegaard is committed to a substantial conception of self-knowledge, but makes no presumption that we generally possess such knowledge by default, it is only natural that the question of how we are to search for self-knowledge should arise in his writings with particular force. How then is this search conceived in Kierkegaard's works? In the first place, and restricting our attention to the case of searching for knowledge of one's own judgements, I think we may associate these works with the following claim: 
(SK1) Searching for knowledge whether one judges that P requires (inter alia) trying to make a judgement whether $P$.

To be sure, the notion of a proposition scarcely has a prominent place in Kierkegaard's writings; much less do we find there a theory of propositions. (We do however find references to the notion of 'thought-content'. .) But SK1 is not supposed to be tied to any particular conception of a proposition. Indeed, this claim can also be formulated, without mention of propositions, as follows: searching for an answer to the question 'What do I think about Q?', where Q is some particular question or issue, requires trying to find an answer to Q itself. But let me introduce this claim in a general way, before turning to its place in Kierkegaard.

The basic motivation for SK1 can be introduced in the form of a certain response to a plausible general constraint on any account of searching for knowledge of one's own mind; namely, the need to properly take into account the distinctive, and distinctively first-personal, way in which such knowledge is typically acquired. According to this response, the first-personal character of my access to what I think about X must be understood by reference to my ability to take up the first-personal question what to think about X. Two points immediately lend some support to this idea. First, it is often observed that, unlike knowledge of other things, knowledge of one's own mind is typically acquired in an immediate way, i.e. non-evidentially and noninferentially, such that claims about one's own judgements and other attitudes have a special epistemic status. That is, I don't typically infer what I think on the basis of my observations about my behaviour, and this makes a difference to the epistemic status of my claims to know my own mind. And second, it is also well attested that acquiring self-knowledge cannot merely be a matter of learning to describe oneself accurately; for there is always the possibility that I truly self-ascribe attitudes with which I nonetheless fail to identify ('appropriate', 'own', regard as mine.) As is familiar from psychoanalytic contexts, it is one thing for me to become aware in a 
purely explanatory and third-personal way that I am possessed by some belief or other attitude; quite another for me to be reflexively aware of this attitude as my own.

These considerations are among those that make it plausible to distinguish between selfascription and avowal, and more generally between regarding oneself as an object and regarding oneself as a subject or agent. Thus, in his important recent book on self-knowledge, Richard Moran argues that these differences are crucial to the asymmetry between the first-person and the third-person points of view, and to the idea of a distinctive mode of access to one's own mental states. Drawing, amongst others, on Sartre and Wittgenstein, Moran writes:

... a report on an attitude of mine has an explanatory basis, grounded in evidence, and need not imply a commitment to the attitude's truth or justification, any more than its thirdperson equivalent would. Instead, the attribution is made in order to identify the states, forces, or whatever else that is driving the actual psychological machinery. An avowal of one's belief, by contrast, is not made on any psychologically explanatory basis, and is rather the expression of one's own present commitment to the truth of the proposition in question ... When I avow a belief, I am not treating it as just an empirical fact about me; ... it is not something I am assailed by, but rather is mine to maintain or revoke (Moran 2001: 86-89).

In Moran's view, this distinctive character of avowals, in contrast with reports, reflects the more general way in which, as he puts it, "being the person whose mental life is brought to selfconsciousness involves a stance of agency beyond that of being an expert witness' (Moran 2001: 4).

What then is the place of these ideas in Kierkegaard? I want to suggest that one of the things we find in his work is a telling critique of a merely 'aesthetic' approach to self-knowledge, and that SK1 is a major upshot of this critique. One plausible way to read the first part of Either 
/ Or, for example, is as a kind of thought-experiment - in Kierkegaard's own terms, an 'imaginary construction' - designed to investigate the question: What would it be for a person to adopt a wholly aesthetic mode of self-regard? For Kierkegaard, who evidently relies in this connection on a broadly Kantian association between aesthetic contemplation and disinterestedness, what is at stake in this question is the idea of a purely contemplative, disinterested, third-personal stance towards oneself. ${ }^{7}$ Part of the historical setting here is of course the apparent celebration of just such a purely aesthetic standpoint in the writings of the Jena Romantics. But Kierkegaard wants to know what a fully realized personification of this stance would look like; hence the shadowy, haunting figure of the 'aesthete' in the first part of Either / Or who, for want of a more familiar name, we come to know as 'A'.

Plausibly, then, the various depictions of aesthetic life in Either / Or are firmly in the subjunctive mood. More: there is arguably a per impossible character to the thought-experiment. ${ }^{9}$ Kierkegaard is not in any straight-forward way offering us a life-style option, to be set off against the choice of a life of ethical or religious commitment, nor is he trying to describe a genuinely traversable stage on life's way. Rather, he is probing the limits and the limitations of a purely speculative or spectatorial stance towards oneself, seeking ultimately to expose what he evidently regards as the comic absurdity implicit in the idea that one might 'take up' such a stance wholesale. In the section entitled 'Either / Or: An Ecstatic Lecture', for example, the aesthete lets us into the secrets of his ecstatic wisdom:

If you marry you will regret it; if you do not marry, you will also regret it; if you marry or if you do not marry, you will regret both. Laugh at the world's follies, you will regret it; weep over them, you will also regret it; if you laugh at the world's follies or if you weep over them, you will regret both; whether you laugh at the world's follies or you weep over them, you will regret both. Believe a girl, you will regret it; if you do not believe her, you will regret it; ... This, gentlemen is the sum of all practical wisdom ... It isn't just in single 
moments that I view everything aeterno modo, as Spinoza says; I am constantly aeterno modo (Kierkegaard 1992: 54-55).

All this apparently comes by way of a satire on the claims made by both the Romantic and Hegelian schools of Kierkegaard's day to have achieved an eternal perspective on the whole, and to have transcended the disjunctive oppositions internal to our ordinary forms of understanding. But what exactly is exposed as lacking in the practical wisdom of a bored, ironic aesthete? Not, certainly, the capacity for acute, urbane and unflinching self-observation and reflection; on the contrary, A's papers overspill with philosophically astute and aesthetically witty self-observations. And yet for all that he hardly manifests himself as the model of a self-knowing agent. In what respect, then, does our aesthete lack self-knowledge?

Kierkegaard does not leave us without a witness in this regard. What is lacking in the aesthete's ecstatic self-contemplation is a temporally situated awareness of himself as a finite agent for whom one's own attitudes are, in Moran's phrase, 'mine to maintain or revoke' - this, at least, is the Judge's assessment of his young friend in Part II of the book. (It is surely significant in this regard that the Judge is, well, a judge.) Accordingly, the Judge gives his own gloss on the famous inscription at Delphi, as follows:

The phrase gnothi seauton is repeated often enough and one has seen in it the aim of all human striving. Quite right, too, but it is equally certain that it cannot be the goal if it is not also the beginning. The ethical individual knows himself, but this knowledge is not mere contemplation, for then the individual would be specified in terms of his necessity; it is a reflection on himself which is itself an action, and that is why I have been careful to use the expression 'to choose oneself' instead of 'to know oneself' (Kierkegaard 1992: 549). 
According to the Judge, then, what would be lacking in a purely contemplative mode of selfregard is an awareness of oneself as an agent, and a proper recognition that one's judgement is called for by questions that matter. ${ }^{10}$ 'What is it, then, that I separate in my either / or?', he writes, 'Is it good and evil? No. I simply want to bring you to the point where that choice truly acquires meaning for you' (Kierkegaard 1992: 485). The Judge's position here is evidently not voluntarism, in the sense of the implausible doctrine that our judgements are under the direct control of our wills; rather, the kind of choice he urges is the second-order decision to take responsibility for a question, and to regard oneself as beholden to judge one way or the other. These ideas bear comparison with a well-known passage from the writings of Gareth Evans:

[1]n making a self-ascription of belief, one's eyes are, so to speak, or occasionally literally, directed outward - upon the world. If someone asks me "Do you think there is going to be a third world war?," I must attend, in answering him, to precisely the same outward phenomena as I would attend to if I were answering the question "Will there be a third world war? (Evans 1982: 61).

Evans' point is sometimes put in terms of 'transparency'; thus, Moran introduces the notion of a 'Transparency Condition', met by a statement of one's belief about X just in case it is made on the basis of 'consideration of the facts about X itself' (Moran 2001: 191). Of course, 'transparency' here is not to be conflated with the notion of being transparent to oneself associated with the 'ethical individual' in Either / Or, what bears comparison with SK1, rather, is the idea that whether I think that $\mathrm{P}$ is 'transparent to' the question whether $\mathrm{P}$, in the sense that I can intelligibly take up the former question by searching for an answer to the latter. Indeed, what SK1 says is that searching for knowledge of one's own judgements requires doing exactly that. ${ }^{11}$ 
We should notice where in Kierkegaard the emphasis lies, however; for his accent is on the sense in which one's properly trying to follow this procedure is itself an achievement, calling for a basic awareness of oneself as a finite agent, given to make judgements. Kierkegaard evidently believed this kind of 'agent's awareness' (to borrow Lucy O'Brien's term) was in grave danger of erosion in his day, and not least at the hands of both Romantic and Rationalist philosophers. ${ }^{12}$ Moreover, pace Moran, whose own emphasis here is on the need to approach questions in a 'deliberative spirit', Kierkegaard draws attention to the possibility that regarding oneself merely as a deliberator may fall short of what is involved in properly regarding oneself as a responsible judge. Indeed, at one point in his letters to A, the Judge goes so far as to say that 'if deliberation were the task for human beings you would be close to perfection', and complains it would be characteristic of his wayward friend to make use of the deliberative possibilities surrounding a question precisely in order to evade it, to avoid letting it matter to him (Kierkegaard, 1992: 484). ${ }^{13}$

None of this of course is to attribute to Kierkegaard an intention to advance a theoretical account, in general and in the abstract, of what it means to be a responsible judge. Rather, he seeks (inter alia) to show what this means by providing portraits of characters who do, and ones who do not, take responsibility for themselves as finite thinkers (more about the significance of this literary strategy later). Nonetheless, I think we can plausibly draw out from his portraits of the aesthete and the Judge a two-fold characterisation of inquiry about one's own judgements as properly outward-looking and prospective. Such inquiry is, first, outward-looking in the sense that it properly looks not to one's inner psychological states, but to the very content of the question at issue. And, second, such inquiry is prospective in the sense that it seeks not to discover something already fixed - that would be for a person to specify himself 'in terms of his necessity' - but rather to bring something about. Life must be lived forwards, Kierkegaard famously reminds us, and he evidently thinks this includes the life of responsible judgement. 
On the face of it, these ideas might seem to fit more naturally into a constitutive or constructivist as opposed to an epistemic account of self-knowledge, i.e. some version of the view that so-called 'self-knowledge' is less a matter of finding something out about oneself than it is of making something true about oneself (cf. Wright 2001). But a note of caution is in order here. For the Judge does not deny that self-knowledge involves contemplation of oneself, only that it can be acquired through 'mere contemplation' (my emphasis). And we should register that Kierkegaard's writings do not consistently follow the Judge's terminological substitution of 'selfchoice' for 'self-knowledge'. ${ }^{14}$ In any case, as we shall now see, the idea of a search for selfknowledge is far from exhausted in Kierkegaard's view by the idea of outward-looking, prospective inquiry.

Perhaps outward-looking, prospective inquiry is all that is needed in a given case in order to search for knowledge of one's own judgements. If it occurs to me to wonder whether I think there will be a third world war, for example, perhaps I should simply try to make up my mind about the matter. But Kierkegaard gives us reasons to think this moral is not generalizable, and that, in an especially important range of cases at least, it is a mistake to think trying to meet the Transparency Condition is all there is to searching for knowledge of one's own judgements. The basic claim here can be summarized as follows:

(SK2) For an important range of cases, searching for knowledge of one's own judgements requires (inter alia) attending to one's own acts of judging, how these acts are performed.

We can introduce the way in which SK1 and SK2 formulate contrasting claims, with the help of the standard distinction between an act of judging and the content of an act of judging. ${ }^{15}$ That is, SK1 
states a certain requirement on trying to determine the content of one's own judgements - i.e. for some $P$, whether one judges that $\mathrm{P}$ - and SK1 says that this requires trying to make a judgement whether P. On the other hand, the import of SK2 is that there are conditions in which seeking knowledge of one's own judgements requires trying not only to determine the content of one's acts of judging, but also attending to the character of these acts as such. Put in one of Kierkegaard's favourite turns of phrase, this claim says there are important contexts in which searching for self-knowledge requires trying to find out not only what one thinks but also bow. ${ }^{16}$

This claim, I submit, is grounded in the way Kierkegaard fundamentally conceives human judgement in general, and ethical and religious judgement in particular. His views in this regard are certainly difficult to untangle from his famous opposition to Hegel, and especially Hegel's conception of 'pure thought'. But a useful starting point is provided by Kierkegaard's curious if often overlooked appeal to the image of a leap in the context of discussions, not about religious faith, but about logic and judgement. Witness the following from his journals:

Basic principles can be demonstrated only indirectly (negatively). This idea is frequently found in Trendlenburg's [sic] Logische Untersuchungen. It is significant to me for the leap .... By analogy and induction the conclusion can be reached only by a LEAP. All other conclusions are essentially tautological (JP 3: 16).

If all too telegraphic, these notes are of some significance since, as Ronald Johnson observes, they represent Kierkegaard’s first substantial entry on 'the leap' (Johnson 1997: 161). Johnson also documents the Aristotelian context of these remarks (via Trendelenburg), and in particular the special notion of 'induction' in play here, as the kind of immediate and direct judgement on which, on pain of a vicious regress, Aristotle apparently thinks all demonstrative reasoning must ultimately depend. What seems reasonably clear, then, is that Kierkegaard associates the image of a leap in this context with the idea of acts of judging that are immediate and direct, that is, 
not mediated by further judgements; a leap, after all, involves getting from A to B without touching any intervening ground. ${ }^{17}$

As many places in his writings also attest, however, Kierkegaard's interest in the idea that our judgements ultimately depend on acts of judging that are immediate and direct goes far beyond any narrow interest in Aristotelian logic. In Philosophical Fragments, for example, it is argued that judgements of the form $A$ exists are brute, in the sense that there can be no nonquestion-begging proof of such judgements, and that all existential judgements must therefore involve 'a leap' on the part of the thinker (cf. $K W$ 7: 43). And throughout Concluding Unscientific Postscript, we find repeated reference to the idea that 'reflection can only be stopped by a leap', where the notion of a leap is glossed as 'something altogether different from the logical' and associated with an act of 'decision' or 'resolution' on the part of the finite thinker (cf. $K W$ 12.1: $113 ; 115-116 ; 335-358) .^{18}$

We may add, moreover, that the central idea here - the idea that our judgements are ultimately based on acts of judging that are immediate and direct - can indeed be plausibly articulated in a quite general way. Consider, for example, the following from David Bell's seminal essay on Kant's Critique of Judgement (Bell's essay is entitled 'The Art of Judgement'):

If we are to avoid the incoherence of a regressive infinity of acts of judgement, or identification, interpretation, understanding or thought, then at some point we must judge immediately, spontaneously - and this means without having already judged, identified, understood, or grasped a thought on the basis of any prior such act. There is simply no room here for an irremovable intermediary (Bell 1987: 226).

According to Bell, this simple line of argument forms the basis of a serious objection to Frege's theory of judgement, but is determinative both for Kant's conception of 'the spontaneity of thought' and for many of Wittgenstein's remarks on rule-following (for example: 'if I have 
exhausted the justifications [sc. for following a rule in the way I do] I have reached bedrock, and my spade is turned. Then I am inclined to say: "This is simply what I do" (Wittgenstein 1953: \$217). ${ }^{19}$ The argument here is not of course that we cannot make judgements based on the apprehension of thoughts (or rules); Kierkegaard, for one, clearly recognizes our capacity to take up cognitive attitudes towards thoughts (he typically refers to such acts in terms of 'reflection' or 'abstract thinking'). The argument, rather, is that the judgements of finite thinkers are ultimately based on what I shall call primitive acts of judging, that is, acts of judging that do not take thoughts as their objects, but on the contrary stand in an immediate and direct relation to what they are about. $^{20}$

No doubt we have to look elsewhere than Kierkegaard's writings for a detailed account of the notion of a primitive act of judging. ${ }^{21}$ But its important place in his thought is manifest in his frequently and sharply expressed opposition to any idea that human thinking is essentially mediated by hypostasized thoughts. Rightly or wrongly - I think rightly, though I shall not argue the point here - Kierkegaard associates just such a conception with Hegel's logic of 'pure thought-determinations'; and it is evidently part of Kierkegaard's aim to provide, against Hegel and in the spirit of Hamann, a critique of the purism of thought (cf. Watts 2007). ${ }^{22}$ The important point here, however, is the positive outcome of this critique: namely, that human judgement cannot ultimately be severed from human spontaneity, as expressed in our primitive acts of judging.

Now, the idea that, contrary to this line of argument, judgement is essentially mediated by abstract thoughts lends support to a certain view of how a person's judgements are in general to be identified. On this view, all that is needed in order to identify a person's judgements in any given case is some suitable method of fixing their content. (This of course allows for a variety of answers to the question what is the right method for fixing the content of thinkers' acts (cf. Higginbotham and Segal 1994)). That Kierkegaard also rejects this view, in this general and unqualified form, is evident from such remarks as the following from Johannes Climacus; 
If a two-year old child could be taught a mathematical thesis, it would be essentially just as true in the child's mouth as in the mouth of Pythagoras. If we taught a two-year old child to say these words "I believe that there is a God" or "Know yourself," then no one would reflect on those words. Is talent itself then not the adequate authority? Do not religious and ethical truths require something else, or another kind of authority, or, rather, what we do actually call authority, for we do, after all, make a distinction between talent and authority? If someone has enough talent to perceive all the implications in such a thesis, enough talent to enunciate it, it does not follow that he himself believes it or that he himself does it, and insofar as this is not the case, he then changes the thesis from a religious to a historical thesis, or from an ethical to a metaphysical thesis ( $K W 7: 152)$.

The basic point here, I take it, is that having the right sorts of cognitive talents may be enough to make a person capable of stating mathematical truths, for example; but that nothing merely of this sort could be sufficient to make a person capable of stating ethical or religious truths as such (we shall shortly consider why Kierkegaard thinks this). But we are also introduced here to the striking idea that, if one enunciates a putatively ethical or religious thesis in a way that lacks the right sort of backing or authority, this has consequences for the very identity of one's claim, such that it is not the ethical or religious claim it seems to be, and which the very same form of words would indeed serve to express when enunciated in more favourable conditions, but must be identified as a claim of some other type; a historical claim, perhaps, or a metaphysical one. ${ }^{23}$

If it is on quite general grounds that Kierkegaard denies human judgement is essentially mediated by thoughts, it should be clear that it is for more local reasons that he denies thinkers' judgements can in general be adequately identified solely by reference to thoughts. That is, this latter denial is based in his views about ethics and religious judgements in particular; this much is clear from the contrast with the mathematical case. So Kierkegaard does not deny that very many 
of a person's judgements can be adequately identified by reference to abstract content; what he denies, rather, is that this is true of one's ethical and religious judgements. Even in the cases of ethics and religion, moreover, Kierkegaard does not deny that an adequate method of identifying a person's judgements will include reference to abstract content; what he denies is that ethical and religious judgements can be identified as such solely or primarily in this way. ${ }^{24}$

The following basic commitments help to explain why Kierkegaard treats ethics and religion as special cases in this regard: first, that ethical and religious claims have imperative force and not, or not merely, assertoric force; second, that such claims make serious demands on one's way of life; and third, that one cannot truly regard a claim as making a serious demand on one's way of life without treating it in an appropriately serious way. This notion of seriousness - or 'earnestness', as Kierkegaard often calls it - calls for closer scrutiny than I can give it here. But these commitments are surely at least intelligible, and help explain why he thinks it only appropriate for us to attend to the character of a person's acts of judging when we try to identify his or her judgements about matters of ethics and religion. Thus, he writes:

In life, the difference is not what is said, but how ... 'How' here is not the aesthetic, the declamatory, whether in flowery language or simple style, whether with sonorous chords or with a screeching voice, whether dry-eyed and unfeeling or tearful, etc. No, the difference is whether one speaks or one acts by speaking, whether one simply uses one's voice, expression, arm movements, a threefold, perhaps fourfold, stress on one word, etc., whether one makes of things like this to exert pressure, to stress a point, or whether to exert pressure one uses one's life, one's existence, every hour of one's day, makes sacrifices, etc. The latter is a high pressure that changes what is said into something quite other than when a speaker says the same thing verbatim ... [There is] an infinite difference in ways of putting one's thoughts into the world (Kierkegaard 1996: 474). 
Plainly, to know 'how thinkers puts their thoughts out into the world' is not here to have a story about the psychological aetiology of their judgements; rather, it is to know whether their judgements are expressed in a way that is glib or serious, second-hand or personally attested. Moreover, it appears that whether a person's speech-acts are in earnest is for Kierkegaard largely a matter of whether they are backed up by his or her primitive acts of judging ('whether to exert pressure one uses one's life ...'). So if we must attend to thinkers' acts of judging as such, in order to identify their judgements about ethics and religion, we must by the same token attend to their primitive acts of judging. In this way, the general notion of a primitive act of judging dovetails with Kierkegaard's specific conception of ethical and religious judgement.

How, then, do these ideas about human judgement in general, and ethical and religious judgement in particular, bear on the search for self-knowledge? Putting aside special features of ethics and religion, there is, I think, a general point to be made here: namely, that in seeking to know one's own judgements one sort of thing we might want to find out is how we are already oriented in a given context by our primitive acts of judging. On the one hand, it seems one might well want to find this out, given Kierkegaard's view that our judgements are ultimately based on such acts. On the other hand, it is difficult to see how a purely outward-looking and prospective stance could be equal to this task. We shall return to this general issue in Section IV below.

But there is also a more specific point here, and the restriction of scope in SK2 - to 'an important range of cases' - is intended to pick up the special status of ethical and religious judgements in Kierkegaard's view. That is, the requirement specified in this claim is to be understood as restricted to those contexts in which he thinks our judgements cannot be adequately identified by reference to abstract content alone. Now, if ethics and religion are contexts of just this sort, a purely content-directed method is presumably no more fit for the purpose of self-ascribing one's own judgements about these matters than it is for ascribing such judgements to anyone else. Hence the claim that, in these contexts, searching for knowledge of 
one's own judgements requires attending to their character qua acts, how these acts are performed.

This claim is made vivid by what Merold Westphal identifies as 'the first concrete satire of Postscript, in which the denizens of Danish Christendom regard as anathema a man to whom it has occurred that it might not be 'quite right for him to call himself a Christian' (cf. Westphal 1996: 54-55):

If he were married, his wife would tell him, "Hubby, darling, where did you ever pick up such a notion? How can you not be a Christian? You are Danish, aren't you? Doesn't the geography book say that the predominant religion in Denmark is Lutheran-Christian? You aren't a Jew, are you, or a Mohammedan? What else would you be then? It is a thousand years since paganism was superseded; so I know you aren’t a pagan. Don't you tend to your work in the office as a good civil servant; aren't you a good subject in a Christian nation, in a Lutheran-Christian state? So of course you are a Christian" (KW 12.1: 50-51).

The satirical point here is not, or at least not merely, that the wife bases her judgement that hubby is a Christian on insufficient grounds - his having been born into a so-called Christian country etc. - but rather that her whole way of comporting herself towards the question what it is to be a Christian, as captured in the satire, is symptomatic of her failure to seriously engage with this question at all. What Kierkegaard thinks she would need to do, to find this out, is not merely to take up outward-looking and prospective deliberations what to think about Christianity, but also to attend to how she is already most basically oriented qua thinker in this regard. As Kierkegaard will sometimes put it, she needs to recover a 'primitive impression' of herself (cf. JP 1: 292).

It should be clear, then, that Kierkegaard associates special requirements with searching for knowledge of one's ethical and religious judgements. But we should also register that it is also 
clearly part of his view that this kind of knowledge, in particular, has a special claim to be called self-knowledge, on the grounds that ethical and religious judgements have to do with what he calls 'the essentially human', the meaning of one's life. It is an overriding concern with the essentially human, for example, that he associates with Socrates' avowed turn away from other things and towards himself; away from questions regarding Pegasus and the Gorgons, as he says in the Phaedreus, and towards the question 'whether I happen to be some wild animal more multiply twisted and filled with desire than Typhon, or a gentler and simpler animal, having by nature a share in a certain lot that is divine and without arrogance' (Plato 1998: 94). (As Kierkegaard is quick to point out, however, there is a paradoxical aspect to Socrates' attitude here: for in the very gesture of turning away from the mythical beings, he is to be found reflecting on the differing natures of these others. As we shall see below, Kierkegaard's conception of the search for self-knowledge turns out to be decisively shaped by the idea that this search may involve others.)

We may conclude that, for Kierkegaard, searching for knowledge of one's own judgements must in general include attending to one's own primitive acts of judging; whether for the general reason that our judgements are ultimately based on such acts, or for the specific reason that we need to attend to such acts in order to know how we truly judge matters of ethics or religion. So if Kierkegaard thinks inquiry about one's own judgements is, or ought to be, outward-looking and prospective - and we have seen that he does think this - his work also affords a contrasting perspective in which such inquiry is properly inward-looking and retrospective: inward-looking, insofar as it requires attending to one's own acts of judging as such; and retrospective, insofar as at a given time and in a given context one will find oneself already oriented by one's primitive acts of judging, in one way or another. 
I turn now to the first of two prima facie problems regarding the search for knowledge of one's judgements, conceived as subject to the requirements specified in SK1 and SK2. This problem can be stated briefly, and arises from the immediately striking fact that these two requirements seem to be in some tension; for how could one coherently take up a stance that is at once outward-looking and prospective, on the one hand, and inward-looking and retrospective on the other? I shall not attempt a full answer to this question here, but I do want to show that Kierkegaard's thought is at least sensitive to the issue and basically intelligible in this regard.

In fact, there is clear evidence that Kierkegaard is not committed to its being possible for a thinker to take up a stance that is at once outward-looking and inward-looking, prospective and retrospective; at least if we read this 'at once' as implying temporal simultaneity. This evidence is provided by Kierkegaard's conception of 'double-reflection', as a distinctive kind of thinking and communication, and as introduced in Postscript as follows:

The reflection of inwardness is the subjective thinker's double-reflection. In thinking, he thinks the universal, but, as existing in this thinking, as acquiring this in his inwardness, he becomes more and more subjectively isolated ....

When a thought has gained its proper expression in the word, which is attained through the first reflection, there comes the second reflection, which bears upon the intrinsic relation of the communication to the communicator and render's the existing communicator's own relation to the idea $(K W 12.1: 73,76)$.

Abstracting from the complications introduced by the theme of communication here, the basic idea is this. ${ }^{25}$ Double-reflection consists of two, temporally distinct parts: in an anterior moment of reflection, the thinker looks outwards, towards 'the universal', 'the idea'; then, in a subsequent moment of reflection, inquiry is turned inwards, towards the thinker's own relation to the content of the first reflection. ${ }^{26}$ So, in the context of our question how in a given case one could 
coherently try to meet both the requirements we have considered, the notion of doublereflection effectively issues the following directive: first try to make a judgement (as per SK1), and then attend to yourself in relation to the content of the judgement you make (as per SK2)!

There is no obvious reason to think this directive is internally inconsistent. But we can admit that the formal notion of double-reflection hardly provides much of a picture of what it would be for a thinker to take up this kind of dual stance. Happily, however, Kierkegaard thinks that Socrates, for one, provides us with just such a picture, a strange and unsettling picture for sure, but a model nonetheless. Thus, according to Kierkegaard's magister dissertation, Socrates' philosophical practice is distinguished above all by the way he is able to relentlessly pursue abstract questions and problems, whilst continually returning to the concrete matter how he himself stands in relation to the questions and problems at issue (cf. Watts 2010). And Kierkegaard's general appreciation of Socrates in this regard comes out nicely in the following from his journals:

Take Socrates! He is not a third person in the sense that he avoids getting into danger, exposing himself or risking his life, as one usually does when he is third person, not an I. By no means. But in danger he himself relates objectively to his own person; in the moment he himself is condemned to death he talks about his sentence as if he were an entirely separate third party. He is subjectivity raised to the second power; his relationship is one of objectivity just like that of a true poet in relation to his poetic production; with this objectivity he relates to his own subjectivity. This is no mean achievement. Generally we get one of two things - either an objective something, an objective piece of furniture that is supposed to be a human being, or we get a jumble of accidental occurrences and arbitrariness. But the task is to relate objectively to one's own subjectivity (JP 4:364). 
This passage surely gives the lie to any lingering impression of Kierkegaard as a 'subjectivist', who wanted to give us licence to abandon the pursuit of objectivity, and give way to 'accidental occurrences and arbitrariness'. On the contrary, what he prizes in Socrates is the way he manages to occupy an objective perspective on himself without losing touch with himself as a finite agent, to whom it is given to make judgements (and face the consequences). Certainly, Kierkegaard thinks this is no mean achievement, and that this duality in Socrates' stance is part of what makes him atopos. But it also appears to be part of Kierkegaard's view that the possibility of 'double-reflection' is attested for us by its actuality in the life of Socrates.

IV

A further problem presents itself, however. As we have seen, Kierkegaard thinks searching for knowledge of one's own judgements must in general include attending to one's own primitive acts of judging; whether for the general reason that our judgements are ultimately based on such acts, or for the specific reason that we need to attend to such acts in order to know how we truly judge matters of ethics or religion. But one might wonder how - in what way, by what means - we are supposed to do this. This question has particular force if we take seriously what I shall call the problem of reflective opacity, where the basic worry here is that we reflective thinkers may come to lose touch with our primitive acts of judging.

Recall our happy-go-lucky civil servant's wife from Postscript. We can suppose that her basic stance towards Christianity is to regard it as nonsense: this is what is displayed by her primitive acts of judging in concrete cases, by how she deploys Christian concepts and by what sense she makes of them in the way she lives out her life: to wit, none. But we may further suppose that she reflectively endorses Christianity, perhaps vigorously defending arguments for the existence of God or the immortality of the soul at civil service dinner-parties. The worry then is that her basic stance towards Christianity is not first-personally available to her, since her 
self-awareness is already mediated by her reflectively endorsed judgements and, especially, by her reflectively endorsed self-image. Her primitive acts of judging are, as we might put it, reflectively opaque to her. Kierkegaard apparently believed his fellow Copenhageners were suffering, en mass, from just this kind of self-blindness; he called it the monstrous illusion of Christendom ( $K W 22$ : 41).

There is a notable historical dimension to Kierkegaard's concern with reflective opacity; for he appears to have been exercised more than most by the hyper-reflective character of modern times, by what he called our 'passionless but reflective age' (KW14: 90). The concern here is that we moderns have become so reflectively sophisticated that we no longer have any primitive awareness of ourselves as agents, no 'primitive impression' of our lives; our so-called thoughts and judgements are second-hand, idle, free-floating, existentially rootless:

If I were to imagine a human being who was brought up in such a manner and lived out his life in such a manner that he never got any impression of himself but always lived by adaptation and comparison - this would be an example of dishonesty. And this is precisely the state of affairs in modern times. The history of the generation runs its course, it is true, but every single individual should still have his primitive impression of existence - in order to be a human being. And as it is with every human being, so also with every thinker - in order to be a thinker (JP 1:292).

Here, then, is Kierkegaard's version of the Rousseauian anxiety that 'as every advance made by the human species removes it still farther from its primitive state, the more discoveries we make, the more we deprive ourselves of the means of making the most important of all' (Rousseau 1973: 43). To be sure, as Johan Taels has emphasized, Kierkegaard's conception of primitivity is not exactly Rousseau's; rather, 'primitivity' here is evidently bound up with Kierkegaard's conception of Socratic, doubly-reflected thinking, as jointly constituted by abstract reflection 
and concrete self-examination (cf. Taels 2003: 57). ${ }^{27}$ Nonetheless, the idea of a 'primitive impression of existence' is evidently part and parcel of Kierkegaard's conception of fullyfledged agent's awareness; and again the emphasis is on the fragility of such awareness. What our times call for, he says, is a 'more primitive thinking' (JP 1: 296).

But the problem remains: how is this 'more primitive thinking' possible for us reflective, self-interpreting beings (and especially for us moderns)? If our self-awareness can be mediated by our reflectively endorsed judgements, and if our reflectively endorsed judgements can come adrift from our primitive acts of judging, we seem to face the difficulty that trying to attend to one's own acts of judging in a given case might be like trying to leap over one's own shadow.

Kierkegaard apparently thinks the problem of reflective opacity runs deep. ${ }^{28}$ But I want finally to show how he offers a cogent response to this problem, based on the following claim:

(SK3) One can attend to one's own acts of judging indirectly, by attending to suitable objects of comparison.

Considered as a response to the problem of reflective opacity, the thinking behind this claim can be presented as follows. If it is possible to recognize one's reflectively opaque acts, it must be possible to do so spontaneously, that is, non-reflectively. But, second, one thing that can indeed serve to elicit the spontaneous recognition of one's own acts is exposure to some suitable object of comparison. And, third, since it is possible to seek out suitable objects of comparison, and to attend to these as such, this amounts to a coherent way of searching for self-knowledge even under conditions of reflective opacity. Finally, then, let me briefly spell out this line of reasoning, and indicate why I think it is central to Kierkegaard's literary practice.

The first step in the proposal is to observe that it would be too quick to infer from the supposition that some of my acts of judging are reflectively opaque to me that these acts cannot be reflexively known or avowed; for not all avowals result from reflection on the content of an avowal and there remains the possibility of spontaneous (non-reflective) forms of recognition. The 
next step is to observe that I might avow my reflectively opaque acts of judging in just such a non-reflective way on the basis of my exposure to suitable objects of comparison. An example, due to Katherine Ramsland, helps bring this idea into view:

... a man who wanted to take great pains to give the impression that he was "cool and detached" was quite vehement when he exclaimed that he "didn't care" about what another person said to him. He invested his denials with so much emotion that the incongruence goaded the other into yelling out, "I don't care either!". The same incongruence between what was said and how it was said was caught in the response of the second man. What the first man could not see when he was actually engaged in it, he saw mirrored back to him through another person's portrayal (Ramsland 1987: 333).

Assuming that it does indeed result in a moment of recognition of the form "That's like me!", Ramsland's story nicely illustrates the possibility of spontaneous avowal through exposure to a suitable object of comparison. Of course the term 'object of comparison' should not mislead us here: we are not to suppose Ramsland's protagonist achieves self-awareness through a reflective process of comparing himself with his interlocutor; rather, he catches himself in the act, so to speak, as a result of his capacity to immediately regard the other as an object of comparison, a mirror of himself. ${ }^{29}$

We can also usefully observe three inessential features of Ramsland's example, however. First, the happy outcome in her story seems more or less adventitious, intended by neither party. But it is not difficult to envisage a case in which one sets out to provide another with a suitable object of comparison. Indeed, it is very plausible that a major part of Kierkegaard's conception of indirect communication, and a major aim of his work in general, is the provision of suitable objects of comparison. Hence Kierkegaard's own prolific use of thought-experiments, pseudonymous authors, stories, parables, diaries and the like. And hence also Kierkegaard's 
abiding interest in the idea of literary works that perform the function of mirrors, as illustrated for example by his extended discourse on the biblical text which invokes 'the mirror of the word' (KW 21: 13ff), or by the Lichtenburg aphorism he used as a motto in Stages on Life's Way: 'Such works are mirrors: when an ape looks in, no apostle can look out' (KW 11: 8). ${ }^{30}$

Second, as Kierkegaard conceives it, communication by means of objects of comparison is a productive, even poetic activity; a matter of artistry. Given the aim to elicit awareness of reflectively opaque attitudes, one especially important part of this art is the ability to construct paradigm cases which not only exemplify judgements, as specified by propositions, doctrines, opinions, hypotheses and the like, but which also serve to make salient concrete ways in which thinkers can be basically oriented in judgement. And the pseudonymous character of many of Kierkegaard's writings, inviting the reader to engage different authorial voices, evidently reflects his basic aim to portray the first-person perspective in concreto. As he reflects in his journals:

I regard it as my service that by bringing poeticized personalities who say I (my pseudonyms) into the centre of life's actuality I have contributed, if possible, to familiarizing the contemporary age again to hearing an $I$, a personal $I$ speak (not that fantastic pure $I$ and its ventriloquism) (JP 1: 302).

As in Ramsland's example, Kierkegaard's fictional authors are often apparently intended to serve to mirror back to the reader an incongruous relationship between 'the what' and 'the how', between the cognitive contents of our reflectively endorsed judgements and the basic character of our acts of judging; but in this case, of course, their doing so is no accident.

Third, whilst Ramsland's example has two protagonists, we should register the possibility of one's constructing in imagination an object of comparison for oneself. This possibility is suggested, for example, by a striking passage in his journals in which Kierkegaard seems to envisage his own literary productivity as a gift that enabled him to become a Socratic teacher to 
himself: Kierkegaard writes of a young man 'favourably endowed as an Alcibiades' who, having lost his way in the world, searches in vain for a Socrates among his contemporaries; 'Then he requested the gods to change him into one' (JP 5: 217). Kierkegaard's perception of his own literary works as playing for himself the role of maieutic teacher is also reflected in his repeated insistence that he has no knowledge of the meaning of these works 'except as a reader' (KW 12.1: 625).

Finally, we need not suppose the only way for something to serve as a suitable object of comparison is, as in Ramsland's example, through a relationship of likeness or imitation.

Certainly, mimesis has a central place in Kierkegaard's own communicative practice; this much is already indicated by the inclusion of the word 'mimetic' in the subtitle of Postscript, for example, and by the major part played in many of his works by such devices as satire, parody, caricature, irony and the like. But it is also clear that Kierkegaard makes use of what we might call inverse exemplars, i.e. objects of comparison designed to elicit self-knowledge through the spontaneous recognition of difference and dissimilarity; the ultra-demanding stance towards religious questions exhibited by 'Anti-Climacus', for one, might be suitable to lead the reader to recognize a certain contrast with his or her own basic orientation to such questions. ${ }^{31}$

At one point in his Essays, Montaigne remarks that 'I find myself more by chance encounters than by searching my judgement' (Montaigne 1965: 27); and Ramsland's story might seem to bear this out. But Kierkegaard's work perhaps shows how the truth in this remark is nonetheless compatible with the idea of a search for self-knowledge. At the very least, we can say that if it makes sense to try to provide suitable objects of comparison for others, it also makes sense to look for such provisions; and the possibility of imaginatively constructing objects of comparison for oneself gives further content to the idea of searching in this way. Moreover, as Kierkegaard makes clear in his discussion of 'the mirror of the Word', he thinks the success of an indirect communication is conditional on the recipient's ability to attend to objects of comparison in the right sort of way: just as there are ways of looking at a literal mirror which 
avoid seeing oneself in it so one must approach an object of comparison in the right sort of way, and attend to it appropriately. 'The first requirement', Kierkegaard writes, 'is that you must not look at the mirror, observe the mirror, but must see yourself in the mirror' (KW 21: 25).

These points raise many further questions, and I have been able here to provide no more than a high-level overview of how Kierkegaard's conceives searching for knowledge of one's own judgements. ${ }^{32} \mathrm{I}$ do hope to have shown, however, that the claims to which I have argued Kierkegaard is committed - as summarized by SK1, SK2 and SK3 - jointly specify a cogent and well-motivated overall account. Still, as Kierkegaard would surely be the first to remind us, it is one thing to think about the search for self-knowledge, quite another to take it up. ${ }^{33}$

\title{
Daniel Watts \\ Department of Philosophy \\ University of Essex \\ Wivenhoe Park \\ Colchester CO4 352 \\ UK \\ dpwatts@essex.ac.uk
}

\begin{abstract}
${ }^{1}$ On the contrary, Kierkegaard evidently has a central interest in the general question how one can know how one is basically constituted as a subject, whether or not one is living in despair, for example.

${ }^{2}$ This sanguine view appears to follow not only from the much-maligned Inner Perception model - what Ryle dubbed 'the hallowed paraoptical model' of the mind 'as a torch that illuminates itself by beams of its own light reflected from a mirror in its own insides' (Ryle 1949: 39) - but also from sophisticated contemporary theories that purport to show, for example, that the possession of self-knowledge follows directly from some basic feature of our rational nature (see, for example, Shoemaker 1994).
\end{abstract}

\footnotetext{
${ }^{3}$ In is important for what follows that we can distinguish between $X$ is required in order to possess selfknowledge and $X$ is required in order to search for self-knowledge. Such a distinction is justified given that meeting a given requirement on searching for self-knowledge may not be sufficient to possess selfknowledge; and that the possession of self-knowledge may not require searching for it.
}

${ }^{4}$ Kierkegaard 1967-78, Vol. 2: 425. Hereafter, this translation of Kierkegaard's journals and papers is cited as " $P$ ", followed by volume and page number. 
${ }^{5}$ One prominent example is the motto for The Concept of Anxiety: 'Socrates still is what he was, the simple wise man, because of the peculiar distinction that he expressed both in words and in life, something that the eccentric Hamann first reiterated two thousand years later: "For Socrates was great in 'that he distinguished between what he understood and what he did not understand"' (Kierkegaard 1978-2000, Vol. 8: 3. Hereafter, this translation of Kierkegaard's writings is cited as " $K W$ ", followed by volume and page number).

${ }^{6}$ See, for example, the comment on Either / Or in Postscript: "There is no didacticizing, but this does not mean that there is no thought-content' ( $K W 12.1: 254)$.

${ }^{7}$ This association between the aesthetic and disinterestedness is made explicit in the following from Postscript: 'Poetry and art have been called an anticipation of the eternal. If one wants to call them that, one must nevertheless be aware that poetry and art are not essentially related to an existing person, since the contemplation of poetry and art, "joy over the beautiful," is disinterested, and the observer is contemplatively outside himself qua existing person' (KW 12.1: 313fn).

${ }^{8}$ The following from Friedrich Schlegel suffices to indicate the background to Either / Or provided by the more programmatic statements of the Jena Romantics: 'Romantic poetry is a progressive universal poetry ... It tries to and should ... make poetry lively and sociable, and life and society poetical' (Schlegel 1971:175).

${ }^{9}$ Though often missed by commentators, the subjunctive and per impossible character of the portraits in Either / Or is forcefully argued in Hartshorne 1990. Tellingly, Kierkegaard remarks in his journals that 'it may legitimately be said that the subjunctive, which occurs as a glimmer of the individuality of the person in question, is a dramatic retort in which the narrator steps aside as it were and makes the remarks as true of the individuality (that is, poetically true), not as factually so and not even as if it may be that, but it is presented under the illumination of subjectivity' (JP 3: 5, my emphasis).

${ }^{10}$ That Moran himself uses the gnothi seauton passage from Either / Or as an epigraph for Chapter Four of Authority and Estrangement ('The Authority of Self-Consciousness') suggests he sees the connections here; and whilst Moran doesn't explore these Kierkegaardian connections it is perhaps significant in this regard that Sartre and Wittgenstein, on whose work he does draw extensively, were both readers of Kierkegaard.

${ }^{11}$ Jonathan Way presses objections to the idea that meeting the Transparency Condition is sufficient for self-knowledge (Way 2007). Note, however, that it is one thing to say, with SK1, that searching for selfknowledge requires (inter alia) following this procedure, another thing to say that doing so is sufficient for 
self-knowledge. As I shall argue below, Kierkegaard, for his part, clearly does not think meeting the Transparency Condition is sufficient in general for self-knowledge.

12 O'Brien writes: 'we are agent-aware of our actions in virtue of carrying them out as a direct result of active consideration of ways we might act' (O’Brien 2007: 120). Kierkegaard writes: 'If in our day thinking had not become something strange, something second-hand, thinkers would indeed make a totally different impression on people, as was the case in Greece, where a thinker was also an ardent existing person impassioned by his thinking' ( $K W 12.1: 308)$.

${ }^{13}$ In fairness to Moran, however, he introduces the notion of a 'deliberative spirit' in a way that casts immediate doubt on whether the aesthete's spirit is properly characterized as deliberative in his sense; thus Moran writes of 'the requirement that I address myself in a deliberative spirit, deciding and declaring myself on the matter' (Moran 2001: 63).

${ }^{14}$ In The Sickness Unto Death, for example, we find: 'The law for the development of the self with respect to knowing, insofar as it is the case that the self becomes itself, is that the increase of knowledge corresponds to the increase of self-knowledge; that the more the self knows, the more it knows itself (KW 19: 31).

${ }^{15}$ The word 'judgement' is often said to be ambiguous with respect to this distinction. I take it, however, that we often use this English word in a more coarse-grained way such that, if we wish to speak here of act and content, we must say that since the word connotes both, it does not admit of disambiguation between the two. Indeed, this linguistic possibility is exploited in my formulation of SK2; this claim does not say that searching for knowledge of one's acts of judging requires attending to one's acts of judging; nor does it say that searching for knowledge of the content of one's acts of judging requires attending to one's acts of judging; what it says is that, in certain cases, searching for knowledge of one's judgements (coarse-grained use) requires attending (not only to the contents of acts of judging but also) to one's acts of judging as such. Needless to say, I try not to trade on any ambiguities in this regard.

${ }^{16}$ For a general account of Kierkegaard on 'the what' and 'the how', see Hannay 2003.

${ }^{17}$ This is perhaps why Paul Holmer can attribute the following thesis to Kierkegaard: 'There is no proof for logical laws or principles ... They describe only the conditions for valid inference; they do not provide logical grounds for being logical. Logic is not its own proof' (Holmer 1957: 39).

18 On how the notions of 'decision' and 'resolution' enter into Kierkegaard's thinking about 'the leap', see Ferreira 1991; Johnson 1997; Stokes 2007. 
${ }^{19}$ Cf. Bell 1979; 1987a; 1987b. The following from Wittgenstein's Nachlass seems even more redolent, against the background of Kierkegaard's appeal to the image of a leap in this context: 'I see that it is red but how does that help me if I do not know what I have to say or how, in some other way, to give expression to my knowledge? For sooner or later I must make the transition to expression. And at this transition all rules leave me in the lurch. For now they all really hang in the air. All good advice is of no help to me, for in the end I must make a leap. I must say "That is red" or act in some way, which amounts to the same thing' (MS 129, cited in Baker \& Hacker 1985: 148).

${ }^{20}$ Compare the way Kierkegaard introduces the notion of concrete thinking (as opposed to 'abstract thinking'): 'What is concrete thinking? It is thinking where there are a thinker and a specific something (in the sense of particularity) that is being thought, where existence gives the existing thinker thought, time and space' (KW 12.1: 332).

${ }^{21}$ One place we might look for elaboration of the notion of a primitive act of judging, for example, is to Christopher Peacocke's account of the notion of the concepts and transitions that a thinker finds 'primitively compelling' (Peacocke 1992: 6). Another, quite different, place is Heidegger's doctoral dissertation The Doctrine of Judgement in Psychologism, in which he rejects any general appeal to the notion that the objects of our judgements have 'some metaphysical standing', existing in a realm distinct from both mind and world, on the grounds that 'such a metaphysical being is never known with that immediacy with which we become aware of the something in question' (cited in Martin 2006: 120).

${ }^{22}$ The following from Postscript is indicative of this critique: 'If Hegel had published his Logic under the title "Pure Thinking," had published it without the author's name, without the date, without notes ... it would have been treated in the Greek way. That is how a Greek would have done it ... Now the Logic with all its notes makes an odd impression, just as if a man were to exhibit a letter fallen from heaven and then even left the blotting paper lying in it, which would all too clearly indicate that the letter from heaven had come into existence on earth' ( $K W 12.1$ : 332-333).

${ }^{23}$ Here, I think, lie the roots of the important Kierkegaardian theme that one can misidentify a person's judgements by misidentifying the 'sphere' in which their judgements are made, e.g. by mistaking for the expression of a religious judgement an utterance which uses such terms as 'God' and 'faith', when really these terms are used in an aesthetic way. On this, see Conant 1995.

${ }^{24}$ The idea that, in ethics and religion, the 'how' has primacy over the 'what' is explicit in Postscript. 'Objectively the emphasis is on what is said; subjectively the emphasis is on how it is said ... Ethically-religiously, the emphasis is again on: how. But this is not to be understood as manner, modulation of voice, oral delivery 
etc., but it is to be understood as the relation of the existing person, in his very existence, to what is said. (KW 12.1: 202-203). That he thinks of this as a matter of priority or 'emphasis', however, shows that Kierkegaard does not regard ethical and religious judgements as lacking cognitive content.

${ }^{25}$ As Martin Andic has observed, Kierkegaard's formulations require a distinction between 'double reflection as such' and 'double reflection in communication'; though the two notions are certainly closely related and are often discussed together. See Andic 1999: 24-25.

${ }^{26}$ That Kierkegaard thinks of these two moments as sequentially ordered is strongly suggested by the tensed constructions in the passage cited ('when ...through the first reflection ... there comes the second reflection...).

${ }^{27}$ Thanks to an anonymous referee of this journal for pressing me to clarify this point about Kierkegaard's general conception of primitivity.

${ }^{28}$ Arguably, Kierkegaard thinks the problem of reflective opacity runs deeper than I have indicated here, and that it is somehow built into the very structure of human selfhood. On this, see Evans (2006); Fingarette (2000); Grøn (2003).

${ }^{29}$ Compare C. S. Lewis: 'Surely what a man does when he is taken off his guard is the best evidence for what sort of a man he is? Surely what pops out before the man has time to put on a disguise is the truth? If there are rats in a cellar you are most likely to see them if you go in very suddenly' (Lewis: 1977: 162).

${ }^{30}$ For fine discussions of the mirror metaphor in Kierkegaard, see Piper 1992 and Stokes 2007. On the long and venerable tradition which holds that we know ourselves through being mirrored by others: See Sorabji 2006: Ch. 13; Bartsch 2006.

${ }^{31}$ For Kierkegaard, moreover, the ultimate inverse exemplar is Christ as the paradox or 'sign of contradiction' who reveals the thoughts of many hearts: 'A contradiction placed squarely in front of a person - if one can get him to look at it - is a mirror; as he is forming a judgement, what dwells within him must be disclosed. It is a riddle, but as he is guessing the riddle, what dwells within him is disclosed by the way he guesses. The contradiction confronts him with a choice, and as he is choosing, together with what he chooses, he himself is disclosed' ( $K W$ 20: 127).

32 One obvious and important further question is what criteria we have for determining whether or not a given object of comparison is a suitable one. For Kierkegaard, at any rate, this question must no doubt be answered ultimately by reference to the special authority of 'the mirror of the Word': '... to see oneself is 
to die, to die to all illusion and hypocrisy', he writes, 'something that can take place only in the mirror of the Word, for otherwise it will become a fraud and one's self-knowledge like the whacks Sancho gave himself' (JP 4: 40).

${ }^{33}$ I have presented versions of this essay at research seminars in Essex, Dublin, Warwick, Southampton and Manchester; my thanks to the participants for very helpful comments. I have especially benefited from conversation with Jeff Byrnes, Wayne Martin, David McNeill, Vasilis Politis, Béatrice Han-Pile and Komarine Romdenh-Romluc.

\section{References}

Andic, M. (1999), 'Love's Redoubling and the Eternal Like for Like' in R. Perkins (ed.), International Kierkegaard Commentary: Works of Love. Macon, Georgia: Mercer University Press.

Baker, G. P. \& Hacker, P. M. S (1985), Rules, Grammar and Necessity. (Oxford, Blackwell). Bartsch, S. (2006), The Mirror of the Self: Sexuality, Self-Knowledge and the Gaze in the Early Roman Empire. London: The University of Chicago Press.

Bell, D. (1979), Frege's Theory of Judgement. Oxford: Clarendon Press.

Bell, D. (1987a), 'The Art of Judgement', Mind, XCVI: 221-244.

Bell, D. (1987b), 'Thoughts', Notre Dame Journal of Formal Logic, 28.1: 36-50.

Conant, J. (1995), 'Putting Two and Two Together: Kierkegaard, Wittgenstein and the Point of View for Their Work as Authors', in T. Tessin and M. von der Ruhr (eds.), Philosophy and the Grammar of Religious Belief(London: Macmillan).

Evans, C. S. (2006), 'Kierkegaard's View of the Unconscious', in his Kierkegaard on Faith and the Self: Collected Essays. Texas: Baylor University Press.

Evans, G. (1982), The Varieties of Reference. Oxford: Clarendon Press.

Ferreira, M. J. (1991), Transforming Vision: Imagination and Will in Kierkegaardian Faith. (Oxford: Clarendon Press).

Fingarette, H. (2000), Self-Deception. Berkeley: University of California Press.

Grøn, A. (2003), 'Mediated Immediacy? The Problem of a Second Immediacy', in P. Cruysberghs, J. Taels and K. Verstrynge (eds.) Immediacy and Reflection in Kierkegaard's Thought. Leuven: Leuven University Press. 
Hannay, A. (2003), 'The 'what' in the 'how", in his Kierkegaard and Philosophy: Selected Essays. London: Routledge.

Higginbotham, J. and Segal, G. (1994), 'Priorities in the Philosophy of Thought', Proceedings of the Aristotelian Society, Supplementary Volumes, 68: 85-130.

Hartshorne, M. H. (1990), Kierkegaard, Godly Deceiver. New York: Columbia University Press.

Holmer, P. L. (1957), 'Kierkegaard and Logic', Kierkegaardiana, 2: 25-42.

Johnson, R. R. (1997), ‘The Logic of Leaping: Kierkegaard's Use of Hegelian Sublation', History of Philosophy Quarterly, 14.1: 155-170.

Johnson, S. (2003), Samuel Johnson: Selected Writings, ed. D. Wormersley, London: Penguin.

Kierkegaard, S. (1949), Either / Or: Volume II, trans. W. Lowrie. Princeton: Princeton University Press.

Kierkegaard, S. (1967-1978), Journals and Papers, trans. H. V. Hong and E. H. Hong. Vols. 1-7. Princeton: Princeton University Press.

Kierkegaard, S. (1978-2000) Kierkegaard's Writings, ed. \& trans. Howard V. and Edna H. Hong et. al., 26 volumes, (Princeton, NJ: Princeton University Press)

Kierkegaard, S (1992), Either / Or: A Fragment of Life, trans, A. Hannay. London: Penguin.

Kierkegaard, S. (1996), Papers and Journals: A Selection, trans. A. Hannay. London: Penguin.

Lewis, C. S. (1977), Mere Christianity. London: Harper Collins.

Martin, W. (2006), Theories of Judgement: Psychology, Logic, Phenomenology. Cambridge: Cambridge University Press.

Montaigne, M. (1965), The Complete Essays of Montaigne, trans. D. M. Frame. Stanford: Stanford University Press.

Moran, R. (2001), Authority and Estrangement: An Essay on Self-Knowledge. Princeton: Princeton University Press.

O’Brien, L. (2007), Self-Knowing Agents (Oxford: Oxford University Press)

Peacocke, C. (1992) A Study of Concepts. Cambridge, Mass.: MIT Press.

Piper, H. (1992) 'The Apostle, the Genius and the Monkey: Reflections on the Mirror of the Word', in G. Pattison (ed.) Kierkegaard on Art and Communication, Basingstoke, Macmillan Press: $125-136$.

Plato (1998), Phaedrus, trans. J. H. Nichols. New York: Cornell University Press.

Ramsland, K. (1987), 'Grice and Kierkegaard: Implication and Communication', Philosophy and Phenomenological Research, 48:2:372-334.

Rousseau, J-J. (1973), The Social Contract and Discourses. London: Everyman.

Ryle, G. (1949), The Concept of Mind. New York: Barnes and Noble. 
Schlegel, F. (1971), Friedrich Schlegel's Lucinde and the Fragments, trans. P. Firchow. Oxford: Oxford University Press.

Shoemaker, S. (1994), 'Self-Knowledge and Inner Sense' Philosophy and Phenomenological Research, 54.2: 249-69.

Sorabji, R. (2006), Self: Ancient and Modern Insights about Individuality, Life and Death. Oxford: Clarendon Press.

Stokes, P. (2007), 'Kierkegaard’s Mirror's: The Immediacy of Moral Vision', Inquiry, 1: 70-94.

Taels, J. (2003), 'A More Primitive Thinking: Word and Speech-Act in Kierkegaard' in P.

Cruysberghs, J. Taels and K. Verstrynge (eds.) Immediacy and Reflection in Kierkegaard's

Thought. Leuven: Leuven University Press.

Way, J. (2007), 'Self-knowledge and the Limits of Transparency', Analysis, 67: 223-30.

Westphal, M. (1996), Becoming a Self: A Reading of Kierkegaard's Concluding Unscientific Postscript. West Lafayette, IN: Purdue University Press.

Watts, D. (2007), 'The Paradox of Beginning: Hegel, Kierkegaard and Philosophical Inquiry', Inquiry, 50.1: 5-33.

Watts, D. (2010), 'Subjective Thinking: Kierkegaard on Hegel's Socrates', Bulletin of the Hegel Society of Great Britain, 61: 23-44.

Wittgenstein, L. (1957), Philosophical Investigations, trans. G. E. M. Anscombe. Oxford: Blackwell. Wright, C. (2001), Rails to Infinity, Cambridge, Mass: Harvard University Press 